\title{
Stimulating Legume Production for a More Sustainable and Nutritious Agriculture
}

\author{
Andrés R Schwember* \\ Department of Plant Sciences, Pontificia Universidad Católica de Chile, Chile
}

*Corresponding author: Andrés R Schwember, Department of Plant Sciences, Faculty of Agronomy and Forest Engineering, Pontificia Universidad Católica de Chile, Av. Vicuña Mackenna 4860, Santiago, 6904411, Chile.

To Cite This Article: Andrés R Schwember. Stimulating Legume Production for a More Sustainable and Nutritious Agriculture. 2020 - 8(6). AJBSR.MS.ID.001331. DOI: 10.34297/AJBSR.2020.08.001331.

Received: 㹃 May 14, 2020; Published: 眥 May 18, 2020

\begin{abstract}
Legume crops are highly valued because of their high grain content of protein and essential amino acids, and other outstanding nutritional properties. The consumption of legumes prevents chronic diseases such as diabetes, obesity, heart ailments and cancer. Also, they are related to sustainable agricultural systems, considering their capacity to associate with atmospheric nitrogen (N) fixing bacteria (Rhizobia), which diminishes the use of synthetic $\mathrm{N}$-fertilizer. In addition, rotating crops with legumes increase the soil quality, and they need less water relative to other sources of proteins. The future of legumes requires the improvement of agronomic practices and breeding new varieties that can cope with the current scenario of climate change, as well as the creation of more nutritional and healthier new legume-based food products.
\end{abstract}

Keywords: Legumes; Sustainable Agriculture; Drought Tolerance; Health Benefits; Nutritious Food

\section{Introduction}

Grain legumes (pulses) are of special importance both from a nutritional and economic point of view due to its presence as staple foods for millions of people worldwide. The legume family (Leguminosae or Fabaceae) encompasses around 12,000 species distributed all over the world and adapted to a large diversity of environments [1], including species such beans, soybeans, chickpeas, lentils, peas, faba beans, among others. In human nutrition, grain legumes are the key source of plant-proteins and peptides (double or triple that of most cereals), complex carbohydrates and dietary fiber, and a good source of some nutrients such as vitamins like folic acid, essential fatty acids and minerals that have significant health benefits [2]. Farmers have grown pulses for their own consumption using low levels of technology in small-scale agriculture in many places of the world [3-5]. For the agricultural sector, legumes comprise direct opportunities based on the three-P dimensions of global sustainability (Planet, People, and Profit) that have been used to describe the term, implying environmental soundness, social equity and economic growth [6], which is fully applicable to sustainable agricultural systems. Under this context, the current global legume production can be analyzed into five main dimensions:

\section{Scientific}

The main limitations affecting the production of legumes are the relatively low increase in yields compared with cereals and the negative effects of biotic and abiotic stress on pulses [7]. Excepting soybean, the production of legumes has been hampered by the lack of varietal protection, especially in developing countries [8], and the limited availability of genomic resources [9]. Unraveling key genetic resources and how plants respond to environmental conditions will allow the development of new strategies for genetic improvement and legume breeding.

\section{Productive}

The cultivation of grain legumes is an alternative of crop rotation in farming systems that is highly dependent on the monoculture of wheat and other cereals, and the incorporation of legumes in the crop rotation would allow soil recovery and diversification of production [10], resulting in enhanced soil biodiversity. They improve soil fertility and reduce the problems associated with soil pests and weeds, which is directly associated with productivity gains in the crop rotations [4]. In addition, several legume species are considered low water users such as chickpea, lentil, common 
pea, faba bean and cowpea that are recommended for cultivation in arid and semi-arid environments where annual rainfall is low (200 to $400 \mathrm{~mm}$ ) [11]. For beef, the water footprint per gram of protein is six times larger than for legumes [12]. All these positive productive components of legumes are directly linked to sustainable agricultural systems.

\section{Environmental}

Inoculation of legume seeds with Rhizobium bacteria is the natural alternative to reduce or eliminate synthetic nitrogen fertilization [13], and this technique is a widely sustainable farming practice used in many parts of the world. This technology brings benefits because allows the fixation of atmospheric nitrogen in the soil, as a result of the symbiotic relationship between Rhizobium and roots of legumes, a distinctive feature of legumes relative to other plant families [7].

\section{Nutritional}

For low-income populations, legumes are staple food providing an inexpensive supply of macro and micronutrients [14], and play an important role in human nutrition since they are a source of protein, energy, certain minerals and vitamins [15]. In addition, legumes are rich in both soluble and insoluble fiber; this dietary fiber is associated with health benefits, especially in relation to cardiovascular disease and digestive disorders [16]. The hypoglycemic effect of the legumes has long been established, in fact, certain legumes (i.e., beans) are known as traditional remedies for diabetes mellitus [17]. Several studies agree that increasing the intake of dietary fiber (soluble or insoluble) induces an increase in postprandial satiety and reduction in subsequent hunger, contributing to body weight control [18]. Pulses also are an important source of proteins that play an important role in human nutrition; in fact, protein rich legumes along with cereals offers one of the best strategies to combat the protein malnutrition [19]. Also, the phenolic compounds represent great potential as functional and nutraceutical ingredients due to the antioxidant and anticarcinogenic properties [20]. Additionally, legumes provide large amounts of vitamin B complex and are important source of folic acid [21], a valuable micronutrient to human health. Thus, legumes not only are a dietary element that maintains basic nutrition; but is also considered natural functional foods that modulate human health and wellness.

\section{Economic}

The main economic impact of the dimensions previously outlined will likely be the recovery of diversity and production of legume crops worldwide. In consequence, and considering that FAO has declared the year 2016 as the "International Year of Pulses" (http://www.fao.org/pulses-2016/en/) and that the European community has adopted a shared strategy for the promotion of legume production in the continent [22], it is reasonable to project a relatively positive global scenario for legume production in the future.

\section{Future Challenges}

In a broad prospective, an integrated strategy comprising stakeholders focusing in the use and management of genetic resources, legume breeding, agronomy, genomics and molecular biology, stress tolerance will be useful to tackle the worldwide challenge of guaranteeing food security as increasing resource demands are required to deal with global climate changes [23]. Due to the increasing water scarcity and global climate change in the world, the combination of various biotechnological and agronomic approaches together with advanced genome editing tools is required to release new drought-tolerant legume cultivars [24]. In addition, heat tolerance in the most important legumes cultivated can be improved via several breeding tools, to enhance production in the field. Besides this, omics methodologies can decipher distinct mechanisms explaining the tolerance to high temperatures, which is crucial to gain insight into the molecular responses associated to thermotolerance [25]. In addition, there is presently a value of the selection methods that strengthen the use of existing genetic diversity among pulses to manage the challenges associated with the biotic and abiotic stresses of climate change [26].

Evaluating the yield gaps in rainfed crops such as legumes is also an important challenge for pulses production in the future [27]. To accomplish quicker genetic gains in legumes grown under rainfed conditions, it was suggested that the integration of modern genomics tools, high throughput phenomics, and simulation modelling in favor of legume improvement will result in enhanced cultivars that adapt well with proper agronomic management [5]. The agronomic improvements of legume production are feasible as a consequence of various practices such as early sowing together with minimum tillage, an effective weed control, and the utilization of green manure. Further, crop rotations (i.e., legumes-cereals) enhance nitrogen availability, optimize weed control, and diminish soil disease attack [28]. Consequently, the incorporation of legumes in the crop rotation will diminish greenhouse gas emissions, reduce the utilization of fossil energy, speed up carbon sequestration in soils, and supply a useful source of feedstock for biorefineries, which explain the high value to grow more legumes in the development of future agroecosystems [29].

Finally, there is a demand by the food industry to create a new generation of processed foods that are low-cost, suitable, tasty, and desirable, although they are also sustainable and healthy, in which legumes have an important role to play in the future [30]. Also, efforts must be made by the food industry to create ready-to-eat, attractive, tasty and convenient legume-based food formulations, resulting in the broadening of more nutritional and healthier diets [31]. 


\section{References}

1. Black M, Bewley JD, Halmer P (2006) The encyclopedia of seeds: science, technology and uses. CAB International, Wallingford, UK, pp. 828.

2. Singh NP, Pratap A (2011) Food Legumes for Nutritional Security and Health Benefits. En: Singh U, et al. (Eds.,) Biofortification of Food Crops. Springer India, New Delhi, p. 41-50.

3. Kebede E (2020) Grain legumes production and prouductivity in Ethiopian smallholder agricutlural system, contribution to livelihoods and the way forward. CogentFood Agric 6: 1722353.

4. Schwember AR, Carrasco B, Gepts P (2017) Unraveling agronomic and genetic aspects of runner bean (Phaseolus coccineus L.). Field Crops Res 206: 86-94.

5. Varshney RK, Thudi M, Pandey MK, Tardieu F, Ojiewo C, et al. (2018) Accelerating genetic gains in legumes for the development of prosperous smallholder agriculture: integrating genomics, phenotyping, systems modelling and agronomy. J Exp Bot 69(13): 3293-3312.

6. (2005) The IUCN Programme 2005-2008. Many voices, one earth, Bangkok, Thailand

7. Rubiales D, Mikic A (2015) Introduction: Legumes in Sustainable Agriculture. Crit Rev Plant Sci 34(1-3): 2-3.

8. Jacob C, Carrasco B, Schwember AR (2016) Advances in breeding and biotechnology of legume crops. Plant CellTiss Org 127 (3): 561-584.

9. Varshney RK, Kudapa H, Pazhamala L, Chitikineni A, Thudi M, et al. (2015) Translational Genomics in Agriculture: Some Examples in Grain Legumes. Crit. Rev. Plant Sci 34(1-3): 169-194.

10. Espinoza S, Ovalle C, Zagal E, Matus I, Tay J, et al. (2012) Contribution of legumes to wheat productivity in Mediterranean environments of central Chile. Field Crops Res 133: 150-159.

11. Chibarabada TP, Modi AT, Mabhaudhi T (2017) Expouding the Value of Grain Legumes in the Semi- and Arid Tropics. Sustainability 9: 60.

12. Mekonnen MM, Hoekstra AY (2012) A Global Assessment of the Water Footprint of Farm Animal Products. Ecosystems 15(3): 401-415.

13. Dalias P (2015) Grain legume effects on soil nitrogen mineralization potential and wheat productivity in a Mediterranean environment. Arch Agron Soil Sci 61(4): 461-473.

14. Ariza Nieto M, Blair MW, Welch RM, Glahn RP (2007) Screening of iron bioavailability patterns in eight bean (Phaseolus vulgaris L.) genotypes using the Caco-2 cell in vitro model. J Agr Food Chem 55(19): 7950-7956.

15. Iqbal A, Khalil IA, Ateeq N, Sayyar Khan M (2006) Nutritional quality of important food legumes. Food Chem 97(2): 331-335.

16. Kadouh H, Zhou K (2012) Nutraceutical and Health Properties of Common Beans (Phaseolus vulgaris). En: Cereals and Pulses. WileyBlackwell p. 187-198.
17. Helmstädter A (2010) Beans and Diabetes: Phaseolus vulgaris Preparations as Antihyperglycemic Agents. J Med Food 13 (2): 251-254.

18. Howarth NC, Saltzman E, Roberts SB (2001) Dietary fiber and weight regulation. Nutr Rev 59(5): 129-139.

19. Batista KA, Prudêncio SH, Fernandes KF (2011) Wheat Bread Enrichment with Hard-to-Cook Bean Extruded Flours: Nutritional and Acceptance Evaluation. J Food Sci 76(1): S108-S113.

20. Dinelli G, Bonetti A, Minelli M, Marotti I, Catizone P, et al. (2006) Content of flavonols in Italian bean (Phaseolus vulgaris L.) ecotypes. Food Chem 99(1): 105-114

21. Petry N, Boy E, Wirth J, Hurrell R (2015) Review: The Potential of the Common Bean (Phaseolus vulgaris) as a Vehicle for Iron Biofortification. Nutrients 7(2):1144-1173.

22. Zander P, Amjath Babu TS, Preissel S, Reckling M, Bues A, et al. (2016) Grain legume decline and potential recovery in European agriculture: a review. Agron Sustain Dev 36: 26.

23. Dwivedi SL, Scheben A, Edwards D, Spillane C, Ortiz R (2017) Assessingand exploiting functional diversity in germplasm pools to enhance abiotic stress adaptation and yield in cereals and food legumes. Front Plant Sci 8: 1461

24. Nadeem M, Li J, Yahya M, Sher A, Ma C, et al. (2019) Research Progress and Perspective on Drought Stress in Legumes: A Review. Int J Mol Sci 20(10): 2541

25. Sita K, Sehgal A, HanumanthaRao B, Nair RM, Vara Prasa PV, et al. (2017) Food legumes and rising temperatures: effects, adaptive functional mechanisms specific to reproductive growth stage and strategies to improve heat tolerance. Front Plant Sci 8: 1-30.

26. Mousavi Derazmahalleh M, Bayer PE, Hane JK, Valliyodan B, Nguyen HT, et al. (2019) Adapting legume crops to climate change using genomic approaches. Plant Cell Environ 42(1): 6-19.

27. Anderson W, Johansen C, Siddique KHM (2016) Addressing the yield gap in rainfed crops: a review. Agron Sustain Dev 36(1): 18.

28. JacobsenSE, Jensen CR, Liu F (2012) Improving crop production in the arid Mediterranean climate. Field Crops Res 128: 34-47.

29. Jensen ES, Steen E, Peoples MB, Boddey RM, Peter M. Gresshoff, et al. (2012) Legumes for mitigation of climate change and the provision of feedstock for biofuels and biorefineries. A review. Agron Sustain Dev 32: 329-364.

30. McClements DJ (2020) Future foods: a manifesto for research priorities in structural design of foods. Food Funct 11(3): 1933-1945.

31. Vaz Patto MC, Amarowicz R, Aryee ANA, Boye JI, Chung HJ, MartínCabrejasMA, et al. (2015) Achievements and Challenges in Improving the Nutritional Quality of Food Legumes. Crit Rev Plant Sci 34(1-3): 105143. 